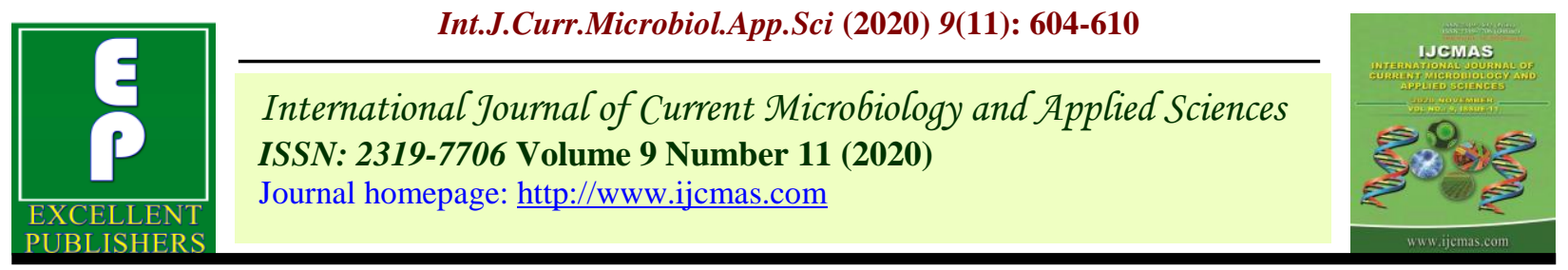

Original Research Article

https://doi.org/10.20546/ijcmas.2020.911.074

\title{
Correlation and Path Coefficient Analysis in Horse Gram [Macrotyloma uniflorum (Lam) Verdec.]
}

\author{
Mukesh Kumar Singh ${ }^{1 *}$, Ruth Elizabeth Ekka ${ }^{1}$, S. K. Sinha ${ }^{1}$, \\ Vivek Kumar Sandilya ${ }^{1}$, Ved Prakash Sahu ${ }^{1}$ and Birjhu ${ }^{2}$
}

${ }^{1}$ Department of Genetics and Plant Breeding, ${ }^{2}$ Department of Entomology, RMD College of Agriculture and Research Station, IGKV, Ambikapur (C.G.), India

*Corresponding author

\section{A B S T R A C T}

\begin{tabular}{|l|}
\hline Ke y w o r d s \\
Horse gram, \\
correlation, Path \\
analysis, \\
[Macrotyloma \\
uniflorum (Lam) \\
Verdec]
\end{tabular}

\section{Introduction}

Pulses play an important role in Indian Agriculture next to cereals, it contributes 25 percent of the global production. Being an indivisible factor of the large majority in human diet. India is the biggest producer of pulses Pulse being continued as important component of the rainfed agriculture, from ancient times lots of the pulses crops are grown under varied agro-ecological conditions.viz. Chickpea, urd bean, pigeon pea, mung bean, lentil, horse gram, field pea,
Horse gram is highly proteinaceous important food legume crop. The present study was conducted at IGKV, RMD CARS, research and instructional farm Ambikapur, during Kharif2019 using 24 genotypes of horse gram. The observation was recorded for eleven characters viz., days to $50 \%$ flowering, days to maturity, plant height, number of branches per plant, number of pods per plant, pod length, number of seed per pod, 100 seed weight, seed yield, biological yield and harvest index to study the correlation and path coefficient analysis. Genotypic correlation of seed yield recorded positive and significant with characters biological yield, number of pods per plant and number of branches per plant indicating dependence of seed yield on these characters. Biological yield, 100 seed weight, harvest index, number of pods per plant, days to 50 percent flowering and number of seed per pod had high positive direct effect on seed yield. These are the important yield component in the present study on horse gram.

lathayrus, cowpea (Chandramohan and Chandragiri, 2007). Horsegram [Macrotyloma uniflorum (Lam) Verdec.] commonly named as kulthiis one of those several valuable legumes that are underexploited at present but can serve as a resource plant for future. Horse gram is highly proteinaceous important food legume crop belongs to family Fabaceae (Datir, 2016). Because of its therapeutic importance, agronomically important traits as well as tolerance of salinity, heavy metals and drought, horse gram is a future pulse crop (Reddy et al., 2008). 
Yield is a complex trait that is highly influenced by the environment and therefore direct selection for yield alone limits the efficiency of selection. Thus effective improvement in yield may be brought about through selection of yield component traits. Yield component traits show association among themselves and also with yield. Correlation is the measure of mutual relationship and degree of closeness between two variables.

Path approach enables the partitioning of the correlation coefficients into the direct and indirect influence of the various characters on yield. The Information on relationship of characters, positive and negative impacts contributed by each character towards yield has an additional favourable position in supporting the selection procedure.

\section{Materials and Methods}

The experimental material for present investigation was consisting of 24 genotypes of horse gram. These genotypes were sown in randomized block design with two replications at IGKV, RMD CARS, research and instructional farm, Ambikapur during Kharif 2019-20. Each genotype was sown as row to row distance of $40 \mathrm{~cm}$. Standard agronomical package of practices was adopted for raising the horsegram crop. The observation was recorded fore leven characters viz., days to $50 \%$ flowering, days to maturity, plant height $(\mathrm{cm})$, number of branches per plant, number of pods per plant, pod length $(\mathrm{cm})$, number of seed per pod, 100 seed weight $(\mathrm{g})$, seed yield ( $\mathrm{q} / \mathrm{ha})$, biological yield and harvest index. Correlation coefficients were estimated for combinations of all the quantitative characters under investigation by formula suggested by Miller et al., (1958) and path analysis by formula suggested by Dewey and Lu (1959).

\section{Results and Discussion}

Extent and direction of relation between two traits is estimated by correlation coefficient and helps in selection for the enhancement of the correlated characters. At genetic level it also used for analysis of strength of relationship of the related characters with yield \& yield attributing traits. The analysis of correlation for yield contributing traits on grain yield is presented in Table 1. Seed yield recorded highly significant positive association with biological yield per plant $(0.647 *)$, number of pod per plant $(0.464 * *)$, but number of branches per plant $(0.303 *)$ significant and positive non significant with plant height (0.279), number of seed per pod (0.172), pod length (0.71) and harvest index (0.056). Whereas it showed highly significant negative association with days to maturity ($0.412 * *)$ and negative non significant association with 100 seed weight (-0.069) and days to $50 \%$ flowering $(-0.058)$ at genotypic level.

Days to $50 \%$ flowering recorded significant positive correlation with pod length and number of seed per pod at genotypic level. It recorded significant positive correlation with days to maturity while significant negative correlation with plant height and number of pods per plant at phenotypic level. Plant height had significant positive correlation with number of pods per plant, number of branches per plant and harvest index at genotypic and phenotypic level. It also had significant positive correlation with biological yield at genotypic level.

Number of branches per plant showed significant positive correlation with biological yield and number of branches per plant at genotypic and phenotypic level only. It also showed significant positive correlation with harvest index at genotypic level. 
Table.1 Genotypic and phenotypic correlation coefficient for quantitative traits in horse gram

\begin{tabular}{|c|c|c|c|c|c|c|c|c|c|c|c|c|c|}
\hline $\begin{array}{l}\text { S. } \\
\text { no. }\end{array}$ & Characters & & $\begin{array}{c}\text { Days to } \\
50 \% \\
\text { Flowering }\end{array}$ & $\begin{array}{c}\text { Plant } \\
\text { height } \\
\text { (cm) }\end{array}$ & $\begin{array}{l}\text { Number } \\
\text { of } \\
\text { branche } \\
\text { s per } \\
\text { plant }\end{array}$ & $\begin{array}{c}\text { Number } \\
\text { of pods } \\
\text { per plant }\end{array}$ & $\begin{array}{c}\text { Pod } \\
\text { length } \\
\text { (cm) }\end{array}$ & $\begin{array}{c}\text { Number } \\
\text { of seed } \\
\text { per pod }\end{array}$ & $\begin{array}{c}100 \\
\text { seed } \\
\text { weight } \\
\text { (g) }\end{array}$ & $\begin{array}{c}\text { Days to } \\
\text { Maturity }\end{array}$ & $\begin{array}{c}\text { Biological } \\
\text { yield }\end{array}$ & $\begin{array}{l}\text { Harvest } \\
\text { index }\end{array}$ & $\begin{array}{c}\text { SeedYie } \\
\text { ld } \\
\text { (q/ha) }\end{array}$ \\
\hline \multirow[t]{2}{*}{1} & \multirow{2}{*}{$\begin{array}{c}\text { Days to } 50 \% \\
\text { Flowering }\end{array}$} & $\mathrm{G}$ & 1 & 0.075 & 0.109 & 0.240 & $0.398 * *$ & $0.337 *$ & 0.112 & 0.054 & -0.233 & 0.159 & -0.058 \\
\hline & & $\mathrm{P}$ & 1 & $-0.360^{*}$ & -0.167 & $-0.304 *$ & -0.023 & -0.034 & 0.198 & $0.662 * * *$ & -0.257 & -0.039 & $\begin{array}{c}- \\
0.518 * *\end{array}$ \\
\hline \multirow[t]{2}{*}{2} & \multirow{2}{*}{$\begin{array}{l}\text { Plant height } \\
\text { (cm) }\end{array}$} & $\mathrm{G}$ & & 1 & $0.457 * *$ & $0.618 * *$ & -0.015 & -0.029 & 0.023 & -0.237 & $0.336 *$ & $0.393 * *$ & 0.279 \\
\hline & & $\mathrm{P}$ & & 1 & $0.394 * *$ & $0.587 * * *$ & 0.062 & -0.010 & 0.044 & -0.235 & 0.185 & $0.356 *$ & 0.254 \\
\hline \multirow[t]{2}{*}{3} & \multirow{2}{*}{$\begin{array}{l}\text { Number of } \\
\text { branches per } \\
\text { plant }\end{array}$} & G & & & 1 & $0.335^{*}$ & 0.263 & 0.243 & 0.168 & 0.028 & $0.459 * *$ & $0.330 *$ & $0.303^{*}$ \\
\hline & & $\mathrm{P}$ & & & 1 & $0.353 *$ & 0.271 & 0.268 & 0.144 & -0.003 & $0.392 * *$ & 0.183 & $0.364^{*}$ \\
\hline \multirow[t]{2}{*}{4} & \multirow{2}{*}{$\begin{array}{c}\text { Number of pods } \\
\text { per plant }\end{array}$} & $\mathrm{G}$ & & & & 1 & $0.384 * *$ & $0.286^{*}$ & -0.115 & $-0.327^{*}$ & $0.323 *$ & $0.568 * *$ & $0.442 * *$ \\
\hline & & $\mathrm{P}$ & & & & 1 & $0.395 * *$ & $0.330 *$ & -0.112 & $-0.296 *$ & 0.245 & $0.397 * *$ & $0.464 * *$ \\
\hline \multirow[t]{2}{*}{5} & \multirow{2}{*}{$\begin{array}{l}\text { Pod length } \\
\quad(\mathrm{cm})\end{array}$} & G & & & & & 1 & $0.730 * *$ & 0.111 & 0.153 & 0.088 & $0.399 * *$ & 0.071 \\
\hline & & $\mathrm{P}$ & & & & & 1 & $0.566 * *$ & 0.134 & 0.081 & 0.048 & $0.411 * *$ & 0.143 \\
\hline \multirow[t]{2}{*}{6} & \multirow{2}{*}{$\begin{array}{l}\text { Number of seed } \\
\text { per pod }\end{array}$} & G & & & & & & 1 & -0.076 & -0.016 & 0.136 & $0.407 * *$ & 0.172 \\
\hline & & $\mathrm{P}$ & & & & & & 1 & -0.061 & -0.076 & 0.070 & $0.302 *$ & 0.219 \\
\hline \multirow[t]{2}{*}{7} & \multirow{2}{*}{$\begin{array}{l}100 \text { seed weight } \\
(\mathrm{g})\end{array}$} & G & & & & & & & 1 & $0.527 * *$ & -0.174 & -0.201 & -0.069 \\
\hline & & $\mathrm{P}$ & & & & & & & 1 & $0.453 * *$ & -0.157 & -0.041 & -0.078 \\
\hline \multirow[t]{2}{*}{8} & \multirow[t]{2}{*}{$\begin{array}{l}\text { Days to } \\
\text { Maturity }\end{array}$} & G & & & & & & & & 1 & -0.213 & -0.186 & - $0.412 * *$ \\
\hline & & $\mathrm{P}$ & & & & & & & & 1 & -0.192 & -0.142 & - $0.387 * *$ \\
\hline \multirow[t]{2}{*}{9} & \multirow[t]{2}{*}{ Biological yield } & $\mathrm{G}$ & & & & & & & & & 1 & -0.173 & $0.647 * *$ \\
\hline & & $\mathrm{P}$ & & & & & & & & & 1 & $-0.367 *$ & $0.557 * *$ \\
\hline \multirow[t]{2}{*}{10} & \multirow[t]{2}{*}{ Harvest index } & G & & & & & & & & & & 1 & 0.056 \\
\hline & & $\mathrm{P}$ & & & & & & & & & & & -0.007 \\
\hline
\end{tabular}


Table.2 Estimates of path coefficient (direct and indirect effects) for various traits on grain yield in horse gram

\begin{tabular}{|c|c|c|c|c|c|c|c|c|c|c|c|c|}
\hline S.No & Characters & $\begin{array}{c}\text { Days to } \\
\mathbf{5 0 \%} \\
\text { Flowering }\end{array}$ & $\begin{array}{l}\text { Plant } \\
\text { height } \\
\text { (cm) }\end{array}$ & $\begin{array}{l}\text { Number } \\
\text { of } \\
\text { branches } \\
\text { per } \\
\text { plant }\end{array}$ & $\begin{array}{c}\text { Number } \\
\text { of pods } \\
\text { per } \\
\text { plant }\end{array}$ & $\begin{array}{c}\text { Pod } \\
\text { length } \\
(\mathrm{cm})\end{array}$ & $\begin{array}{l}\text { Number } \\
\text { of seed } \\
\text { per pod }\end{array}$ & $\begin{array}{c}100 \\
\text { seed } \\
\text { weight } \\
(\mathrm{g})\end{array}$ & $\begin{array}{l}\text { Days to } \\
\text { Maturity }\end{array}$ & $\begin{array}{l}\text { Biological } \\
\text { yield }\end{array}$ & $\begin{array}{l}\text { Harvest } \\
\text { index }\end{array}$ & $\begin{array}{l}\text { Seed } \\
\text { Yield } \\
(\mathbf{q} / \mathbf{h a})\end{array}$ \\
\hline 1 & Days to $50 \%$ Flowering & 0.135 & 0.010 & 0.014 & 0.032 & 0.054 & 0.045 & 0.015 & 0.007 & -0.031 & 0.021 & -0.058 \\
\hline 2 & Plant height $(\mathrm{cm})$ & -0.022 & -0.292 & -0.133 & -0.180 & 0.004 & 0.008 & -0.006 & 0.069 & -0.098 & -0.114 & 0.279 \\
\hline 3 & Number of branches per plant & -0.015 & -0.065 & -0.144 & -0.048 & -0.037 & -0.035 & -0.024 & -0.004 & -0.066 & -0.047 & $0.302 *$ \\
\hline 4 & Number of pods per plant & 0.046 & 0.120 & 0.065 & 0.195 & 0.075 & 0.055 & -0.022 & -0.063 & 0.063 & 0.111 & $0.441 * *$ \\
\hline 5 & Pod length $(\mathrm{cm})$ & -0.109 & 0.004 & -0.072 & -0.105 & -0.273 & -0.199 & -0.030 & -0.041 & -0.024 & -0.109 & 0.071 \\
\hline 6 & Number of seed per pod & 0.024 & -0.002 & 0.017 & 0.021 & 0.053 & 0.073 & -0.005 & -0.001 & 0.01 & 0.029 & 0.172 \\
\hline 7 & 100 seed weight $(\mathrm{g})$ & 0.045 & 0.009 & 0.067 & -0.046 & 0.044 & -0.030 & 0.402 & 0.211 & -0.070 & -0.080 & -0.069 \\
\hline 8 & Days to Maturity & -0.018 & 0.082 & -0.009 & 0.114 & -0.053 & 0.005 & -0.183 & -0.348 & 0.074 & 0.064 & $-0412 * *$ \\
\hline 9 & Biological yield & -0.197 & 0.284 & 0.388 & 0.273 & 0.074 & 0.115 & -0.147 & -0.180 & 0.846 & -0.146 & $0.646^{* *}$ \\
\hline 10 & Harvest index & 0.052 & 0.128 & 0.108 & 0.185 & 0.128 & 0.133 & -0.065 & -0.060 & -0.056 & 0.327 & 0.055 \\
\hline
\end{tabular}


Number of pods per plant had significant positive correlation with harvest index, plant height and number of seed per pod while significant negative correlation with days to maturity at genotypic and phenotypic level. It showed significant positive correlation with biological yield at genotypic. Pod length showed significant positive correlation with number of seed per pod, harvest index at genotypic and phenotypic level. Number of seed per pod showed significant positive correlation with harvest index at both level. 100 seed weight showed significant positive correlation with days to maturity at both level. Similar result recorded by Prakash and khanure (2000),Prabha et al., (2010), Shrivastava and Singh (2012), Sinha and Kanwar (2014),Sunil et al., (2014) and Vijay kumar et al., (2016).

Path coefficient analysis was used to split the correlation coefficients among seed yield as dependent variable \& its component characters into direct and indirect effects. The analysis of path coefficients for yield contributing characters on seed yield are presented in Table 2. In the present investigation it was found that biological yield per plant recorded highest positive direct effect $(0.846)$ on grain yield per plant followed by 100 seed weight (0.402), harvest index (0.327), number of pods per plant (0.195), days to $50 \%$ flowering (0.135). The character number of seed per pods (0.073) exhibited relatively low magnitude of positive direct effects on grain yield. The characters days to maturity (-0.348), plant height ($0.292)$, pod length $(-0.273)$ and number of branches per plant $(-0.144)$ showed negative direct effect.

Days to $50 \%$ flowering exhibited negligible positive indirect effect via pod length (0.054), number of seed per pod (0.045), number of pods per plant (0.032), harvest index (0.021), 100 seed weight (0.015), number of primary branches (0.014), plant height (0.010), days to maturity (0.007).While it showed negligible negative indirect effect (-0.031) via biological yield per plant. Plant height exhibited low negative indirect effect via number of pod per plant (-0.180), number of primary branch (0.133), harvest index (-0.114). It also exhibited positive indirect effect via days to maturity (0.069). Number of primary branches exhibited negative negligible indirect effect via biological yield per plant (0.066), number of pod per plant (-0.048), harvest index (-0.047), pod length (-0.037), number of seed per pod (-0.035) and 100 seed weight $(-0.024)$.Number of pods per plant exhibited low positive indirect effect via plant height (0.120), harvest index (0.111) and negligible positive indirect effect via pod length (0.075), biological yield (0.063), number of seed per pod (0.055).Pod length exhibited low negative indirect effect via number of seed per pod (-0.199), harvest index (-0.109) and negligible negative indirect effect via days to maturity $(-0.041)$, 100 seed weight (-0.030), biological yield per plant (-0.024).Number of seed per pod exhibited positive indirect effect via harvest index (0.029), biological yield per plant (0.01). 100seed weight exhibited moderate positive indirect effect via days to maturity (0.211). While, it showed negative indirect effect via harvest index (-0.080) and biological yield (-0.070). Days to maturity exhibited low positive indirect effect via number of pods per plant (0.114) and negligible positive indirect effect via biological yield per plant (0.074) and harvest index (0.064). While, it showed low negative indirect effect via 100 seed weight ($0.183)$.Biological yield per plant exhibits high positive indirect effect via number of branches per plant (0.388). It exhibits moderate positive indirect effect via plant height (0.284), number of pods per plant (0.273) and low positive indirect effect via number of seed per pod (0.115).It also 
exhibits low negative indirect effect via days to $50 \%$ flowering $(-0.197)$, days to maturity ($0.180), 100$ seed weight (-0.147) and harvest index (-0.146).Harvest index exhibits low positive and indirect effect via number of pods per plant $(0.185)$, number of seed per pod (0.133), pod length and plant height (0.128) but negligible negative indirect effect via 100 seed weight $(-0.065)$, days to maturity $(-0.060)$ and biological yield per plant ($0.056)$.

Similarly Prakash and khanure (2000) recorded highest positive direct effect on yield per plant, by test grain weight and number of branches. Paliwal et al., (2005), recorded positive direct effect on seed yield for branches per plant, pods per plant and 100 seed weight. Bhave et al., (2007) for plant height. Khulbe et al., (2013), recorded that pods per plant and 100 seed weight had positive direct effect on seed yield.

In conclusion the analysis of correlation carried out eleven characters indicates significant positive relationship of seed yield with biological yield per plant, number of pods/plant and number of branches/plant. Path analysis recorded that biological yield/plant, 100 seed weight, harvest index, number of pods/plant, days to 50 percent flowering, number of seed per pod, and revealed positive direct effect on seed yield. These are the important yield component in the present study on horse gram.

\section{References}

Bhave, S.G. Joshi, S.N., Sawant, S.S., Bendale, V.W and Desai, S.S., 2007, Analysis of genetic parameter for yield and certain yield contributing traits in horsegram. J Maha. Agric. Uni., 32 (2): 239-241

Chandramohan S, Chandragiri KK. 2007. Effect of organic manures on growth and yield attributes in cotton + blackgram intercropping system. International Journal of Plant Science.; 2(1):156-160.

Datir SS (2016) Genetic improvement in horse gram [(Macrotyloma uniflorum (lam) verdec.] (syn. Dolichos biflorus L.) through induced mutations, Journal of Food Legumes, 29(3\&4): 174-179

Dewey, D.R. and K.H. Lu, 1959. A correlation and path coefficient analysis of components of crested wheat grass and seed production. Agron. J., 51: 515-7

Khulbe, R.K., Pant, D.P. and Singh, D. V., 2013 Genetic studied in horsegram from NW Himalayan regions of Uttarakhand, India crop res., Hisar 43 (1/2/3): 194-196.

Miller, P.A, Williams, J.E., Robinson, H.F. and Comstock, R.E. 1958.Estimataes of variance and co- variance in upland cotton and implication in selection. Agron J., 50: 126-131

Paliwal, R.V., Sodani, S.N. and Jain, L.K., 2005 Correlation and path analysis in horse gram (Macrotyloma uniflorum). J.Arid leg., (2): 309-310.

Prabha, S.S., Rajendra Prasad and Sambhoo Prasad., 2010, Study on genetic and seed quality parameter in horse gram genotype under mid hills of north western Himalaya. Trends in Biosci., 3(2): 187-189

Prakash, B.C and Khanure, S.K 2000. Genetic parameters, correlation and path coefficient analysis in horsegram. Karnataka J. Agric. Sci., 13(2): 313-31

Reddy, P.C.O., G. Sairanganayakulu, M. Thippeswamy, P.S. Reddy, M.K. Reddy, and C. Sudhakar (2008). Identification of stress- induced genes from the drought tolerant semi- arid legume crop horsegram [Macrotyloma uniflorum (Lam.) Verdc.] through analysis of subtracted expressed 
sequence tags. Plant Science, 175(3): 372-3

Sinha. S. K. and Kanwar Raja Ram. (2014) National Conference on pulses: Challenges and Opportunities under Changing Climate Scenario $29^{\text {th }}$ September- $1^{\text {st }}$ October 2014, JNKV Jabalpur (M.P): pp. 3.38.

Srivastava, R.L. and Singh, G. 2012. Genetic variability, correlation and path analysis in mung bean (Vigna radiata (L.). Indian Journal of Life Science, 2: $61-65$

Sunil Neelam, Vinod Kumar, Sivaraj Natarajan, Kamala Venkateshwaran and Someswara Rao Pandravada, (2014). Evaluation and Diversity Observed in Horsegram (Macrotyloma uniflorum (Lam) Verdc.) Germplasm from Andhra Pradesh, India International Journal of Plant Research, 4(1): pp. 17-22.

Vijayakumar, A. G. Shruti Koraddi, Ishwar H. Boodi And D. T. Kallesh (2016) Genetic Variability Studies In Horse Gram (Macrotyloma uniflorum (Lam.) Verdc.) The Biscan an international quarterly journal of life science 11(2): pp. 1255-1259.

\section{How to cite this article:}

Mukesh Kumar Singh, Ruth Elizabeth Ekka, S. K. Sinha, Vivek Kumar Sandilya, Ved prakash sahu and Birjhu. 2020. Correlation and Path Coefficient Analysis in Horse Gram [Macrotyloma uniflorum (Lam) Verdec.]. Int.J.Curr.Microbiol.App.Sci. 9(11): 604-610.

doi: https://doi.org/10.20546/ijcmas.2020.911.074 